\title{
UCLA Teach-In on Vietnam War
}

\author{
March 24, 1966
}

Beerman joined the eminent philosopher Herbert Marcuse, his friend Stanley Sheinbaum, and others at a teach-in on the Vietnam War at the UCLA campus in Westwood, as can be seen in the teach-in program that follows. As a confirmed pacifist, Beerman was deeply concerned about the war and the escalating loss of life that followed President Johnson's decision to increase air attacks on the North Vietnamese in 1965. In this talk, Beerman opened by situating the war in the twenty-year "adventure" into conflict that was the Cold War. The enmity issuing from the Cold War, he suggested, yielded no winners or losers, just more insensitivity to the desires and needs of the putative enemy.

Beerman held both sides in the Vietnam War responsible. The American aerial assault was, to his mind, "repugnant." But he also lamented the fact that North Vietnam, like the United States, held to "the arrogant certainty of its own utter rightness." The moral blindness from this certainty exacted a very heavy toll in human lives, as Beerman would continue to call out and mourn until the war's end.

"It was the best of times; it was the worst of times. It was the age of wisdom; it was the age of foolishness. It was the season of Light; it was the season of Darkness. It was the spring of hope; it was the winter of despair. We had everything before us. We had nothing before us. We were all going direct to Heaven; we were all going direct the other way..."

With these bitter words Charles Dickens opened his novel A Tale of Two Cities. The paradoxes to which he addressed himself persist in our time.

To live in the midst of such paradoxes is the particular challenge and burden of our generation. 


\title{
VIETAMM TEACHIIN
}

\author{
presented by
}

THE UCLA VIETNAM DAY COMMITTEE

12 Noon - 12 Midnight

MARCH 25, 1966

Grand Ballroom

Student Union

UCLA Campus

FIGURE 16. UCLA Teach-In I (1966). 


\section{Noon-12:35 SI CASADY}

Immediate past president, California Democratic Council; owner and publisher of the El Cajon Valley News; winner of the first annual editorial competition sponsored by the So. Calif. ACLU in 1964.

\section{2:35-1:00 STANLEY SHEINBAUM}

Staff member, Center for the Study of Democratic Institutions, Santa Barbara; former consultant to the Government of Vietnam; coordinator, Public Admin. and Economics, MSU Vietnam project.

\section{1:00-1:45 FELIX GREENE}

Author of the book, China, and the producer of the documentary film, China; recent visitor to North Vietnam; reporter, traveler, former commentator for $\mathrm{CBC}, \mathrm{BBC}$.

\section{1:45-2:15 RUSSELL JOHNSON}

Peace Education Secretary, New England region, American Friends Service Committee; director, Quaker Conferences in Southern Asia, 1961-65; recent visitor to South Vietnam and Sou theast Asia.

\section{2:15-2:45 WILLIAM WORTHY}

News analyst; reporter for Baltimore Afro-American; visitor to Cuba, China, Southeast Asia, South Africa; Ford and Nieman Foundation Fellow.

\section{2:45-3:00 BERTRAND RUSSELL TAPE}

A message recorded especially for this Teach-In.

\section{3:00-3:30 BEN MARGOLIS}

Los Angeles lawyer, specialist in labor and constitutional law; member, International Law Committee, National Lawyers Guild; co-author, Lawyers Brief on Vietnam.

\section{3:30-3:45 ENTERTAINMENT - JOSEPH BYRD AND THE WORKERS}

\section{3:45-4:00 LEONARD LEVY}

National Vice-President, Amalgamated Clothing Workers of America, AFL-CIO.

\section{4:00-4:30 RABBI LEONARD BEERMAN}

Temple Leo Baeck; special field of interest in ethical implications of religion to areas of social concern.

\section{4:30-5:00 FRANK GREENWOOD}

Author of the play, If We Must Die. 


\section{5:00-5:30 ARTHUR CARSTENS}

Senior staff member, Institute of Industrial Relations, UCLA; candidate for the Democratic nomination to Congress from the 27 th Congressional district.

\section{5:30-6:00 ENTERTAINMENT - NEW FOLKSAY SINGERS AND LENNY HAROLD}

\section{6:00-6:30 DON WHEELDIN}

Immediate past president, Pasadena CORE; author; veteran of World War II; on faculty of the New Left School.

\section{6:30-7:00 MARSHALL WINDMILLER}

Associate Prof. of International Relations, San Francisco

State; co-author of Communism in India; editor of The

Liberal Democrat; foreign affairs commentator on $\overline{\mathrm{KPFK}}$.

\section{7:00-7:25 WILLIAM WINTER}

News analyst; correspondent; publisher of William Winter Comments.

\section{7:25-7:35 REV. STEPHEN FRITCHMAN (Moderator)}

Minister, First Unitarian Church of Los Angeles; leading peace advocate; writer, lecturer on social and religious problems and contemporary society.

\section{7:35-8:00 HERBERT MARCUSE}

Professor of Philosophy, UC San Diego; formerly, OSS and State Dept., 1942-50; Senior Fellow, Russian Institute, Columbia U.; Senior Fellow, Russian Research Center, Harvard.

\section{8:00-8:45 MRS. FANNY LOU HAMER}

Representative of the Mississippi Freedom Democratic Party; appeared on nationwide TV and radio to defend civil rights.

\section{8:45-9:00 ENTERTAINMENT - MIKE JANUSZ}

International folk singer

\section{9:00-9:30 MRS. DOROTHY HEALEY}

Southern California chairman, Communist Party, USA; former Deputy State Labor Commissioner, former International Vice-President, Cannery and Agricultural Workers Union, CIO.

\section{9:30-9:50 ISIDORE ZIFERSTEIN}

Psychiatrist; Research Psychiatrist, Institute for Psychiatric and Psychosomatic Research, Mt. Sinai Hospital; lecturer and author on the psychology of war. 
Forces of change beyond the control of even the best men are pushing aside the remaining ramparts of the old certainties, those truths, those values which once sheltered and comforted us. Peace is cracked in a hundred shivers. The air of the Cold War sweeps through the long winter night. In America we look outward and the world envies or despises or distrusts us, we look inward and are plagued by the rising tide of the poor, the urban hopeless, the massive and still unresolved protest of the Negroes.

We seem to be living at the end of one era and the beginning of another. And it can be emotionally wearing to be living at such a time, vaguely knowing that something is coming to an end, and something is being born.

For twenty years we have been living through a time euphemistically called a Cold War. For twenty years our government and its people have been acting on the assumption that communism is on the march for the conquest of the world, that it is the manifest destiny of the United States to save the world from suffering this fate. In the pursuit of this mirage, this myth, we have engaged in international adventurism. In the process our hands are covered with blood. We have become as brutalized as our enemies, as we have shown in Vietnam, torturing, killing, burning, combatants and non-combatants alike.

For twenty years we have sacrificed upon the altar of war and its preparation the greatest gifts of this nation, the gifts of mind and technique and sensitivity, and in so doing, we have demonstrated a total contempt for man.

This same era has given us a glimpse of what man's knowledge could have done for us. But we have made no serious effort to bring this golden age into being. Compassion has not been a full-time occupation for any of us. Our ingenuity, our resources, have literally been swallowed up by our consuming endeavor to stalk the enemy. Our laboratories, our universities, our research centers have found themselves dedicated to the same pursuits.

For twenty years the angel of death has hovered over our civilization, fending off any serious endeavor to re-cultivate the waste places or to make a serious assault upon the problems of human anguish. The efforts of the so-called Great Society are so feeble and shabby they can hardly be considered more than a token of what needs to be done.

The result of all this cannot adequately be measured, but you and I know it in the form of greater frustration and estrangement. The poor know it in the form of even greater poverty. For it is upon the poverty of [the] multitude that the unswerving, irresponsible, irrepressible, dedication to defense and war is built.

Such an age as ours may very well bring tourists to the moon but it will hardly make a contribution to the human spirit. For in such an age, the artists, the thoughtful man, the man of wisdom, the student, even the man of religion, is no longer able to see the healing role the responsible use of his talents would demand of him.

It is in the context of such a time that we have come, with all of our different and sometimes contradictory points of view, to consider the war in Vietnam. 
And it frightens me to think that I do not have all the solutions to the conflict. It frightens me because I think I am, as Americans go, reasonably informed and intelligent and concerned. It frightens me to think what I think may never reach that cold heart where computers calculate the risk of continuing, enlarging, or ending the conflict.

And yet it frightens me even more to contemplate how I should be able to face the ugliness of my own silence in the presence of what I know to be criminal, the brutalization of our moral sensitivity, the indifference with which we learn of the daily body count.

I am not a military strategist. I was a terrible soldier. I cannot write a novel, or make a television set or send a rocket to the moon. But does that mean that I cannot make an intelligent judgment on whether a work of fiction or a television program is worthwhile, or whether the moon is not better off being just for lovers rather than for American or Russian tourists?

We are responsible for anything against which we do not protest. What we do here then is an expression of that responsibility. If we speak of the tragedy of Vietnam and the failure of governments to end that conflict, we think not only of Vietnam, but of a world torn by contending ideologies and ambitions. It is our task to articulate the human conscience in a world in which the conscience is shrunken, shriveled, petrified, rarely able to move beyond the narrow boundaries we have set for it.

Each of the contending ideologies is wrapped in the arrogant certainty of its own utter rightness. Our country asserts its determination to stop ruthless Communist aggression, to defend freedom for Vietnam and the world. North Vietnam, the National Liberation Front, the People's Republic of China proclaim their intention to throw back the ruthlessly aggressive American imperialists in defense of the right of the Vietnamese to govern themselves, and on behalf of all nations seeking national liberation.

We know what price has been paid for this relentless, passionate dogmatism. In Vietnam, war has become a way of life, conscripting the young, making widows, orphans. Freedom and justice are hollow words, a mockery. They mean torment. Both sides have been forced to commit atrocities to mock their claims of self-righteousness. Both have been drawn farther and farther into the maelstrom of destruction.

Surely we must know that war cannot serve the interests of man any longer. In this age, with these weapons, how can war do anything but destroy our hopes, our accomplishments, our pretensions of humanity? There is no moral justification for the horror that our planes, our massive firepower, our brutality have inflicted upon the people of Vietnam.

"All I ask," Albert Camus once told us, "is that in the midst of a murderous world we agree to reflect on murder and to make a choice. After that we can distinguish those who accept the consequence of being murderers themselves or the accomplices of murderers, and those who refuse to do so with all their force and being." 
The United States has made such a choice, and we find it repugnant. We call upon our government to stop the air attacks as an affront to human decency and unworthy of a great people. We call upon our government to express a clear intention that it intends to end the war with a settlement that will include withdrawing its forces and dismantling its military basis. Such a pronouncement supported by immediate and meaningful actions to prove our good faith is necessary if either the regime in Saigon or the NLF or the N. Vietnamese will take seriously overtures to negotiate.

The people and government of North Vietnam and the NLF have chosen whether they will be murderers or accomplices of murderers, and we must be shocked and repelled. We must address to them this appeal to abandon the methods of torture, assassination, the terror. They too are an affront to the whole concept of human decency.

We ask of them that they declare their unqualified willingness to meet with representatives of the United States and the present government of S. Vietnam to negotiate peace based on the agreements of 1954 .

It is difficult to imagine that a world such as ours, divided by suspicion and hatred, is capable of turning from war and toward the resolution of conflict by non-violent means. Yet this is the choice we must make. Whether or not we will compromise with murder.

We need those who have the muscle to care. And more than caring we need those who have the courage to be compassionate, who will preserve and cultivate an enduring vision of the good and the tender. ${ }^{1}$

\section{COMMENTARY BY RABBI SANFORD RAGINS}

Psychologist Carl Rogers taught that therapists must use words as scalpels-not to wound, but to heal. That aptly describes how Leonard Beerman, a therapist of the conscience, often worked, as in this powerful talk early in the war in Vietnam. A new term-"body count"-had just been added to the American vocabulary. Leonard immediately saw the horror and suffering lurking behind this ugly euphemism, and he resolved to use his words to awaken our consciences.

And what powerful words they were!

Incisive, even blunt: "Our hands are covered with blood."

Sharp: "Peace is cracked in a hundred shivers."

Eloquent: "It is our task to articulate the human conscience in a world in which the conscience is shrunken, shriveled, petrified, rarely able to move beyond the narrow boundaries we have set for it."

Challenging and tough, indeed penetrating: "We are responsible for anything against which we do not protest."

Leonard's passionately held core beliefs are also evident.

His pacifism: "Surely we must know that war cannot serve the interests of man [sic! ] any longer." 